第 11 表 液処理主要設備

\begin{tabular}{|c|c|}
\hline 設 & 仕 \\
\hline 中和原液貯 槽 & $200 \mathrm{~m}^{3} \times 2$ 槽 \\
\hline 中 和 反 応 槽 & $10 \mathrm{~m}^{3} \times 2$ 槽 $280 \mathrm{~m}^{3} \times 1$ 槽 \\
\hline 石こう沂過機 & $48 " \prime \times 22 \mathrm{~kW}$ 遠心分離機 $\times 2$ 基 \\
\hline 収銅原液貯 槽 & $200 \mathrm{~m}^{3}$ \\
\hline 集荷銅液貯 槽 & $150 \mathrm{~m}^{3} \times 4$ 槽 \\
\hline 収銅反応槽 & 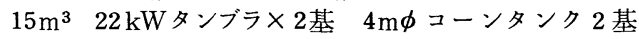 \\
\hline 沈殿銅洰過機 & $42 " \times 15 \mathrm{~kW}$ 遠心分離 $\times 2$ 槽 フィルタプレス $\times 2$ 基 \\
\hline 鉄 酸 化 塔 & $2 \mathrm{~m} \phi \times 16 \mathrm{mH} \times 2$ 基 液体酸素 $10 \mathrm{t}$ 貯槽 \\
\hline 鉄 反 応槽 & $10 \mathrm{~m}^{3} \times 2$ 槽 $\quad 500 \mathrm{~m}^{3}$ シックナ \\
\hline 鉄殿物沪過機 & $23 \mathrm{~m}^{2}$ ドラムフィルタ 真空ポンプ $55 \mathrm{~kW}$ \\
\hline 鉛 反応槽 & $10 \mathrm{~m}^{3}$ 液体塩素 $1 \mathrm{t} \times 3$ 本 $50 \mathrm{~m}^{3}$ 貯槽 \\
\hline 鉛殿物洰過機 & $30 \mathrm{~m}^{2} 0.4 \mathrm{~m}^{3}$ フィルタープレス $\times 2$ 基 $50 \mathrm{~m}^{3}$ 洰液貯槽 \\
\hline 亜鉛反応槽 & $10 \mathrm{~m}^{3} \times 3$ 槽 $500 \mathrm{~m}^{3}$ シックナ \\
\hline 水酸化覀鉛沪過機 & $25 \mathrm{~m}^{2}$ ドラムフィルタ $\times 2$ 基 真空ポンプ $37 \mathrm{~kW} \times 2$ 基 \\
\hline 亜鉛殿物乾燥炉 & $1.4 \mathrm{~m} \phi$ 流動乾燥炉＼cjkstart重油焚エヤヒーター \\
\hline 塩化亜鉛貯槽 & $50 \mathrm{~m}^{3} \times 3$ 槽 \\
\hline 第 2 亜鉛反応槽 & $10 \mathrm{~m}^{3} \quad 500 \mathrm{~m}^{3}$ シックナ \\
\hline 塩カル貯槽 & $150 \mathrm{~m}^{3} \quad 250 \mathrm{~m}^{3} \quad 600 \mathrm{~m}^{3}$ \\
\hline 塩カル濃 縮 塔 & $2.9 \mathrm{~m} \phi \times 12 \mathrm{mH}$ \\
\hline
\end{tabular}

坂鉱業所で製鍊される。ガス処理工程から回収される硫酸鉛と液 処理で回収する鉛殿物も $\mathrm{Pb}$ 製鍊原料として小坂へ送る。

水酸化亜鉛殿物は重油然焼熱風で流動乾燥してから濃塩酸に溶 解して50\%の塩化要鉛液として外販している。

$$
\text { 3. よ め }
$$

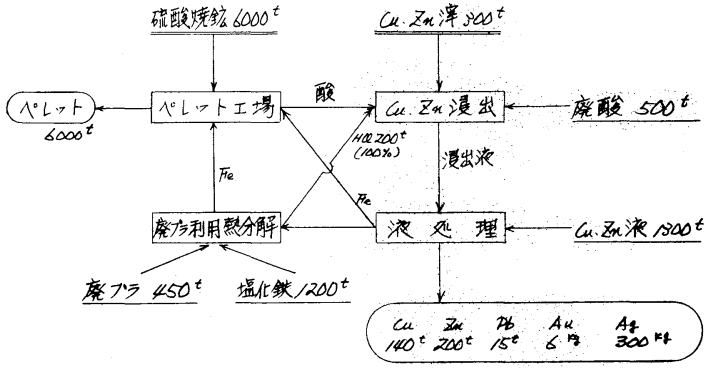

第6図 操業のバランス（t/月）

以上のように，主原料である焼鉱の極端に減少した状況の中 で，いかにして現有設備の有効活用により産廃系原料からの非 鉄金属回収を增加させるか, 相互のバランスを保ちながらの操 業面での努力を続けている。

公称 $28,000 \mathrm{t} /$ 月の塩化揮発ペレットプラントに対し, 原料 減によりペレット生産量の現状は $6,000 \sim 8,000 \mathrm{t} /$ 月に止つて いるが, 含 $\mathrm{Cu}$ 含 $\mathrm{Zn}$ 涬類, スラッジ類, 含 $\mathrm{Cu}, \mathrm{Zn}$ 廃液, 塩 化鉄廃液, 廃硫酸, 廃塩酸, 廃プラスチック等の活用資源化 により非鉄金属類に関しては， $\mathrm{Au} ， \mathrm{Ag}$ を除きおおむねぺレッ トフル生産時以上の生産を確保し, また資源再利用の面から各 廃棄物排出工場に対して, また地域環境面に対して, いささか の貢献をしているものと確信している。

\title{
Chloride Volatilization and Metal Recovery from Industrial Waste at Dowa Seiko
}

\author{
by Soji KOBAYASHI
}

In 1969 at Amagasaki Plant of Dowa Seiko, we completed the construction of the chloride volatilization plant which could produce iron oxide pellets of $28,000 \mathrm{t} / \mathrm{m}$ with recovery of non-ferrous metals such as $\mathrm{Cu}, \mathrm{Pb}, \mathrm{Zn}, \mathrm{Au}$ and $\mathrm{Ag}$ from contaminated pyrite cinder used as the raw material. And we have continued the operation for about ten years since then.

Meanwhile, in the field of the sulphuric acid production, there has been a remarkable change in the situation of raw materials. Therefore pyrite cinder entering Amagasaki Plant decreased year by year, and at present the plant is forced to run at one fourth of the full capacity.

In order to keep the production level of $\mathrm{Cu}$ and $\mathrm{Zn}$, however, various kinds of industrial waste containing $\mathrm{Cu}$ and $\mathrm{Zn}$ (sludge and solution) have been treated for the purpose of recovering them. So that at present more than $80 \%$ of $\mathrm{Cu}$ and $\mathrm{Zn}$ products come from that industrial waste. And at the same time dirty pickled liquor of steel $\left(\mathrm{FeCl}_{2}\right.$ solution containing $\mathrm{Pb}$ and $\mathrm{Zn}$ ), which is collected from the small mills making wires and nails, etc., in the surrounding area, is decomposed with hot air by the conversion of discarded plastic, and recovered dilute $\mathrm{HCl}$ solution (about $10 \%$ ) is served to leach metals in sludge in stead of acid produced from the chloride volatilization plant.

As mentioned above, the chloride volatilization plant, in which the pellets production is cut back by the decrease of raw material, can produce even more metal products than at the full operation.

Thus we contribute to the recycle of the pregnant resources and to solve the environmental problems in this district.

\section{[3-21] 岡山製錬所の最近の操業について}

1. はじめに

同和鉱業株式会社岡山製鍊所は, わが国最大級の生産能力を有 する硫酸製造設備を中心に, 硫化鉄鉱の大型集約化処理をおこな つているが，おのおのの生産能力は下記の通りである。
硫酸 (発煙硫酸を含む)
$70,000 \mathrm{t} /$ 月
焼 鉄 鉱
$35,000 \mathrm{t} /$ 月

1. 正会員 同和釷業株式会社岡山製鍊所

2. 同和鉣業株式会社岡山製鍊所

$$
\text { 原田謙 三 }{ }^{1} \text { 小野崎 淳 } \text { 夫 }^{2}
$$


の意義を継承して同和鉱業における鉄と硫黄のセンターとして今 日に至つている。

製鍊所設立以降, 生産規模の拡大・供給原料の変更等, 幾多の 变遷を経験しているが，その沿革はつぎのとおりである。 1951 年 6 月 西日本化学工業 (株) を設立。硫酸工場の建設に 着工

1953年 10 月 同和鉱業 (株)が経営の委託をうけ岡山製鍊所と して，3,000 t / 月の硫酸工場の操業を開始し，焼鉱は焼結鉱と して製鉄メーカに出荷。

1956 年 7 月 硫酸製造設備を倍增し, 2 系列で $6,000 \mathrm{t} /$ 月 となる。

1960 年 10 月 電気炉を建設し銅製鍊を開始, 電気銅 $420 \mathrm{t} /$ 月。

1961 年 9 月 硫酸製造設備をさらに 1 系列増設し, $10,000 \mathrm{t}$ /月になる。

1962 年 2 月 銅電解工場の増設工事完了し, 生産能力は電気 銅 $950 \mathrm{t}$ / 月となる。

1968 年 4 月 高品位酸化鉄 $430 \mathrm{t} /$ 月の商業ベースによる生 産を開始。

1969 年 10 月 従来の硫酸工場をスクラップダウンし, 大型硫

酸設備を新設。 $33,000 \mathrm{t} /$ 月

1970 年 10 月 高品位酸化鉄製造設備を更新し， $2,500 \mathrm{t} /$ 月 に能力アップ。

1973 年 4 月 硫酸製造設備に発煙硫酸製造設備を併設し $40,000 \mathrm{t} /$ 月に能力アップ。

1974 年 9 月 第 2 期の大型硫酸製造設備の建設を完了し, 硫 酸生産量は, $70,000 \mathrm{t} /$ 月の規模となる。

1980 年 10 月 高品位酸化鉄の増産工事に着工。

この間の銅製鍊設備の建設，焙焼技術の開発，および操業成績 については既報 ${ }^{1)}$ のおりである。

\section{2. 硫酸製造部門}

産業活動の拡大と技術革新への飽くなき挑戦が続けられる一方，

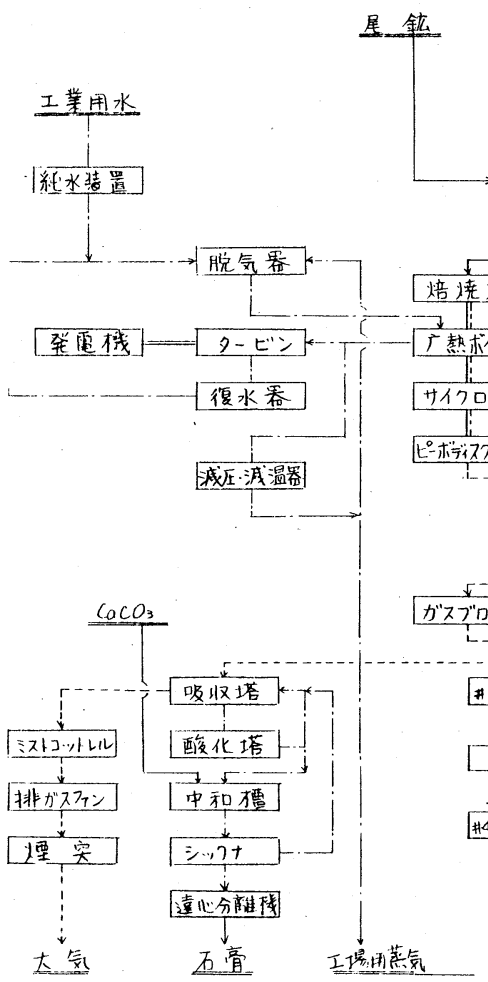

次第に環境問題もクローズアップされだしてきた 1960 年代の半 ばにあつて, 製鉄メーカより硫酸焼鉄処理における $\mathrm{SO}_{x}$ 問題が 提起されるに及んで，硫化鉱専焼の硫酸製造は大きな方向転換を 迫られることとなつた。当社は硫化鉄鉱の生産会社であるところ から，通産当局から打出された合理的処理と大規模化を主眼とす る硫酸センター構想の意を受け，第一期硫酸センターの建設に踏 み切つた。

工事は 1968 年早春に着工し, 翌年 9 月スタートした。日産 $1,300 \mathrm{t}$ の生産能力は, 硫化鉄鉱焙焼の硫酸設備として斯界最大 級の設備であり，今日まで順調な操業を続けている。原料は秋田 県北鹿地帯の黒鉱随伴硫化鉄鉱で, 少量の有価非鉄金属を含有す る焼鉄鉱は光和精鉱 (株) 戸畑および同和精鉱 (株) 尼崎において光 和プロセスによる塩化揮発処理をおこなつて金・銀・銅その他有 価金属を回収ののち高炉用ペレットとして出荷されている。

一方, 随伴硫化鉱と同様に合理化を必要とした柵原産硫化鉄鉱 に対してもほぼ同規模の硫酸七ンター構想を適用することとし， 1974 年 10 月この第二期工事を完成した。この設備は B 系設備と 呼称され，原料形態の相違のほかはほぼ $\mathrm{A}$ 系設備（第一期設備） と同様の工程から成つている。 2) 3 )

これらの建設については『硫酸と工業』誌で紹介したとおりで ある。

\section{$2 \cdot 1$ 設備の特徵}

2 度の大規模製造設備の工事にあたつて, 従来の設備規模を大 幅に上回る建設工事であるので, 次の基本的な方針によることと した。

（1）大規模設備であるので, 不時のトラブルが製品の需給上に 大きな影響を与えるとともに，環境に及ぼす影響も無視できない ので, プラントの安全かつ安定した連続操業を維持できるよう技 術的な検討を実施した。

（2）廃液・廃ガス・騒音等による鉱害を未然に防止するための 万全の対策を実施する。廃液はクローズドシステムとして系内に 繰返えし使用し, 廃ガスはダブルコンタクト方式と高煙突を採用 する。（1974 年以降はさらに排脱設備を完備した。）
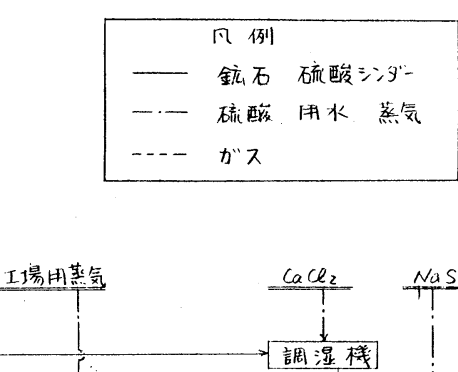

NaSH
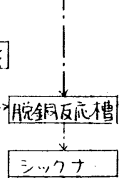

$714)^{*} 7^{\circ} \circ 2$

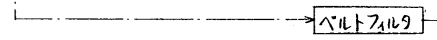

价デションクーラ
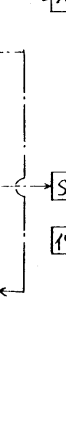

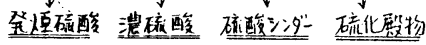

第 1 図＼cjkstart硫酸部門設備系統図
(3) 大型設備としての スケール・メリットを最 大限に確保するため, 操 業の自動化・計測化をは かり集中管理を可能にし て, 人員配置に十分な配 慮をする。

(4) 副産する焼鉄鉱の 品質が光和プロセスによ つて高炉原料として活用 できるように，厳密な焙 焼部門の操業コントロー ルを容易にする。

（5）鉄・硫黄の実収率 の向上のほか, 廃熱をエ ネルギー源として有効利 用し, 自家発電を設置す る。

\section{$2 \cdot 2$ 設備ならびに 操業の概要} 第 1 図。主要設備仕様は 第 1 表, 第 2 表のとおり
設備のフローシートは 
である。以下設備・操業の説明は主 にA系設備について述べる。主な操 業のデータは第 3 表, 第 4 表に示す。

$2 \cdot 2 \cdot 1$ 給釷・焙焼設備 原料の黒鉱随伴硫化鉄鉱は浮選精鉱 であるため粒子径が細かく，水分も $10 \%$ 以上を含み粘性が強いので, 焙 焼炉一連続・均一給鉣することが困 難である。湿式給鉱は乾式給鉱に比 べて熱回収の面では不利ではあるが， 焼鉄鉱の品質確保のめには, 焙焼炉 内の酸素分圧のコントロールが不可 欠の要因であるので, 敢えてスラリ 一状にして炬内への均一給鉱をする 方式を採用した。鉱石をスラリー状 にするための水分は, 硫酸工程等で 発生する廃酸を利用し系内繰返しを 計つている。

なお， B 系設備は原料が扱い易い 粒状であるため完全な乾式給鉱方式 とし，余熱の十分な回収を図る設計 となつている。

$2 \cdot 2 \cdot 2$ 廃熱ボイラ・発電設備 当所でも多年の実績がある川崎ラ モンドボイラを採用した。この種の ボイラでは伝熱面の一部にダストが 堆積すると,ガス流の偏流が発生し て局部摩耗を生じ易いので, ハンマ ーリング装置には十分に配慮した。 発生蒸気は, 一部を工程用で使用す るほかは, 復水タービン型発電機に 送気して発電に使用している。

$2 \cdot 2 \cdot 3$ ガス精製設備 ガス の除塵・冷却・洗浄のために, テト ラクロン,ピーボディスクラバーな らびにミストコットレルを設置して いる。ガスの冷却については, 当社 小坂鉱業所等で実績のあるガスクー ラでは, 多量の凝縮水が生成し水: ランスの面で問題があるので, 蒸発

による冷却方式として真空冷却装置を採用した。

$2 \cdot 2 \cdot 4$ 転化・吸収設備 転化器は, $(3+1)$ 方式から なる 4 層 4 パスのダブル・コンタクトで 6 基の熱交換器と転化器 から構成されている。落は, 発煙硫酸設備を追加建設したので, 乾燥塔を含めて 4 塔から構成されている。酸の冷却設備は, 海水 による冷却でイリゲーション・クーラを設置しているが， B 系設 備は, 設置面積・海水節約・海水蒸気による腐蝕防止・製品酸の 品質向上の面からテフロン・クーラを採用した。なお, ガスブロ アは焙焼炉が 2 基必要であつたために操業管理が安全かつ容易な ことから 2 台の併列運転の方式とした。

$2 \cdot 2 \cdot 5$ 焼鉱処理・廃酸設備廃熱ボイラ, サイクロン等 で回収した焼鉄鉱は, 次の塩化揮発処理の工程で必要とする塩化 カルシウム溶液と調湿用の廃酸とともに調湿機内で混合調湿し, スクラバで捕収した焼鉄鉱粉のフィルタケーキとともに焼鉄鉱貯 鉱舎へ送鉱する。

廃酸については既述のとおり鉱石スラリー化のための.水分や炉
第 1 表 硫酸製造設備主要機器設置一覧表

A 系 統（湿式給釷焙㜣ニケミコ式ダブルコンタクト硫酸設備）

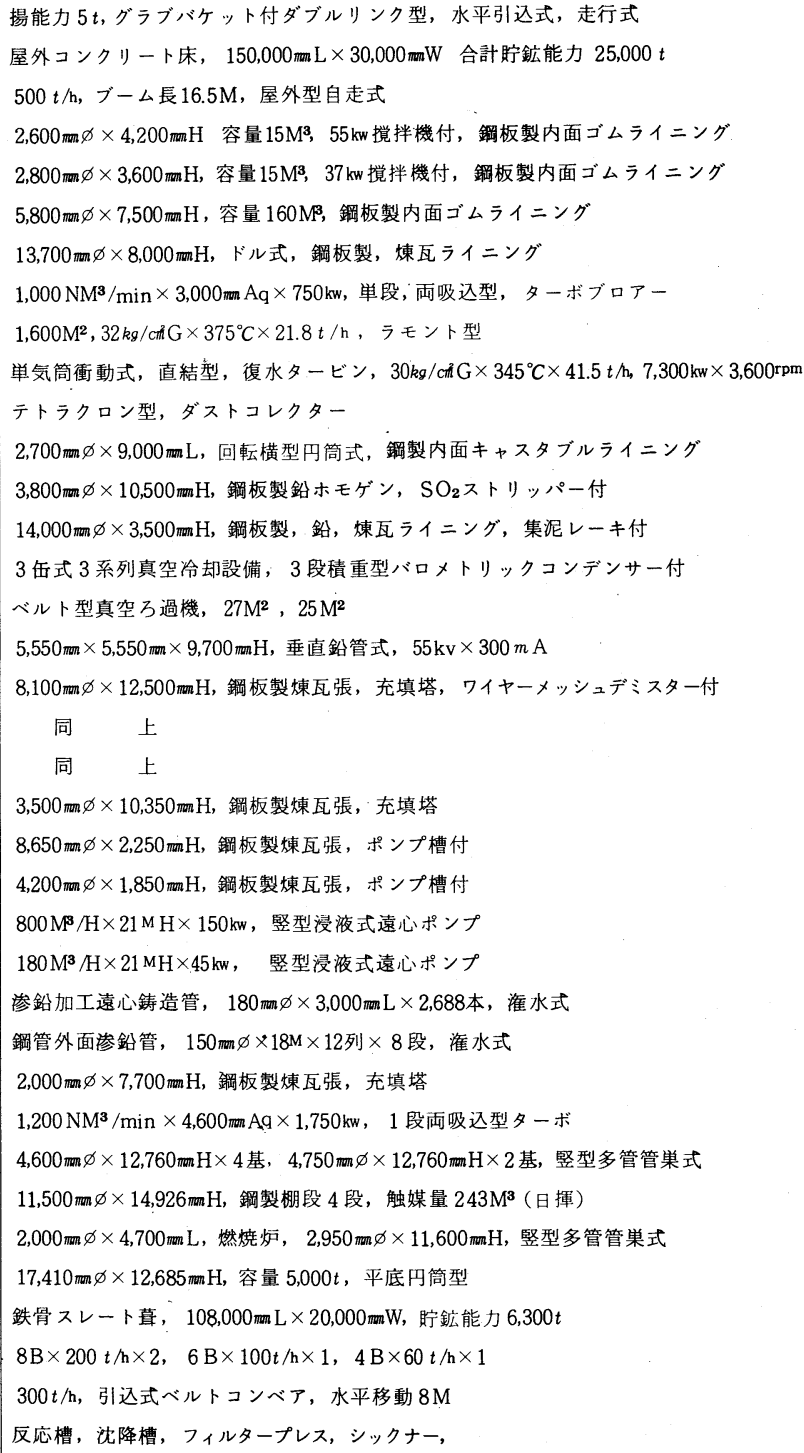

第 3 表 原料ならびに製品の分析例

\begin{tabular}{|c|c|c|c|c|c|c|c|}
\hline [ 原料鉱石] & $S$ & $\mathrm{Fe}$ & $\mathrm{Cu}$ & $\mathrm{Zn}$ & $\mathrm{Pb}$ & $\mathrm{SiO}_{2}$ & $\mathrm{CaO}$ \\
\hline 松 峯 鉱 & 50. 18 & 43. 94 & 0.37 & 0. 20 & 0.14 & 2. 92 & 0.06 \\
\hline 内 の 袋 鉱 & 47. 15 & 41. 31 & 0.38 & 0. 47 & 0.37 & 6. 51 & 0.08 \\
\hline 柵 原 鉱 & 46. 58 & 42. 40 & 0.14 & 0. 30 & 0.01 & 4. 70 & 0.52 \\
\hline
\end{tabular}

\begin{tabular}{cc|c|c|c|c|c|c|c}
\hline \multicolumn{10}{c|}{ 製品焼鉱 } & $\mathrm{S}$ & $\mathrm{Fe}$ & $\mathrm{Cu}$ & $\mathrm{Zn}$ & $\mathrm{Pb}$ & $\mathrm{SiO}_{2}$ & $\mathrm{CaO}$ \\
\hline 焼 & 鉄 鉱 & 0.42 & 61.98 & 0.44 & 0.47 & 0.22 & 4.79 & 0.26 \\
& " & 0.62 & 60.53 & 0.49 & 0.49 & 0.25 & 5.66 & 0.39 \\
\hline
\end{tabular}

(単位 p.p.m)

\begin{tabular}{|c|c|c|c|c|c|c|c|c|}
\hline 〔製品硫酸 ] & $\mathrm{H}_{2} \mathrm{SO}_{4}$ & $\begin{array}{l}\text { 遊 離 } \\
\mathrm{SO}_{3} \%\end{array}$ & $\mathrm{Fe}$ & 強残 & $\mathrm{Pb}$ & $\mathrm{F}$ & $\begin{array}{l}\text { 還元 } \\
\text { 物質 }\end{array}$ & 沃素価 \\
\hline $\begin{array}{l}\text { 濃、硫 酸 } \\
\text { 発 煙 硫 酸 }\end{array}$ & $\begin{array}{c}98.46 \\
-\end{array}$ & $\begin{array}{c}- \\
28.7\end{array}$ & $\begin{array}{l}16 \\
15\end{array}$ & $\begin{array}{l}20 \\
25\end{array}$ & $\begin{array}{l}<0.01 \\
<0.01\end{array}$ & $\begin{array}{l}<0.1 \\
<0.1\end{array}$ & $\begin{array}{r}4.4 \\
53.9\end{array}$ & \\
\hline
\end{tabular}


第 2 表 硫酸製造設備主要機器設置一覧表

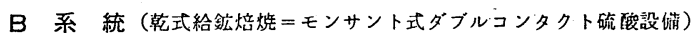

\begin{tabular}{|c|c|c|}
\hline 储 & 基数 & 式 ・ 仕 \\
\hline 硫 化 鉱 ビ ン & 2 & 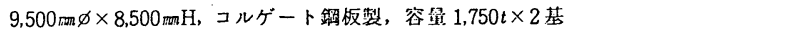 \\
\hline クッションホッパー & 1 & 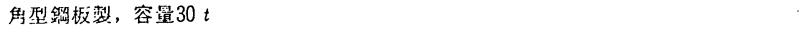 \\
\hline 流 钩 焙 焼 炉 & 1 & 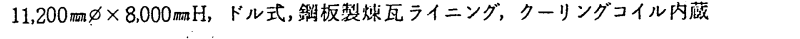 \\
\hline テーブルフィーダー & 3 & 円简型， 2 個所切出式，給鉱容勧 $3 \sim 15 i / \mathrm{h} /$ 基 \\
\hline 空気プロアー & 1 & $1,400 \mathrm{NM}^{3} / \mathrm{min} \times 3,000 \mathrm{~mm} \mathrm{Aq} \times 1,200 \mathrm{kw}$, 単段ダーボブロアー \\
\hline 涗熱ボイ・ラー & 1 & $2,600 \mathrm{M}^{2}, 32 \mathrm{~kg} / \mathrm{m}^{2} \mathrm{G} \times 375^{\circ} \mathrm{C} \times 52.0 \mathrm{t} / \mathrm{h}$, ラモント型 \\
\hline 発電機 & 1 & 単気筒衙動式直結形後水タービン, $30 \mathrm{~kg} / \mathrm{cmG} \times 345^{\circ} \mathrm{C} \times 42.8 \mathrm{t} / \mathrm{h}, 8,000 \mathrm{kw} \times 3,600 \mathrm{rpm}$ \\
\hline サ1 ク & 1 & テトラクロン型， $2,100 \mathrm{man} \varnothing \times 10,200 \mathrm{~mm} \mathrm{H}$ \\
\hline かルサインンクラー・ & 1 & $1,500 \mathrm{~mm} \phi \times 2,500 \mathrm{rm} \mathrm{H}$, 間接冷却式 \\
\hline 焼 鉱 調 湿 機 & 1 & $2,800 \pi m \varnothing \times 10,000$ mn $\mathrm{L}$, 回䎐横型円简式, 鋼板製内面キャスタブルライニング $45 \mathrm{kw}$ \\
\hline ピーボディスクラバー. & 1 & 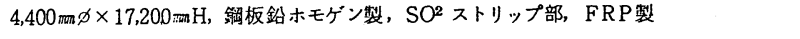 \\
\hline 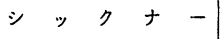 & 1 & $14,000 \mathrm{~mm} \varnothing \times 3,500 \mathrm{~mm} \mathrm{H}$, 鋼板ゴムライニング，要部煉瓦内張 \\
\hline 薄硫酸冷却設 整 & 1 & 1 午式タワー型, 真空冷却設備 \\
\hline ミストコットレル & 4 & $5,500 \mathrm{~mm} \times 5,500 \mathrm{~mm} \times 9,700 \mathrm{~mm} \mathrm{H}$ ，垂直鈆管式，55kv $\times 300 \mathrm{~m} \mathrm{~A}$ \\
\hline 乾㙅塔 & 1 & $7,000 \mathrm{~mm} \varnothing \times 10,520 \mathrm{~m} \mathrm{H}$, 鋼板製煉瓦内張, 充填塔, ワイヤーメッシュデミスター付 \\
\hline 中 間 吸 収 & 1 & 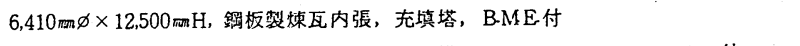 \\
\hline 最終吸収塔 & 1 & 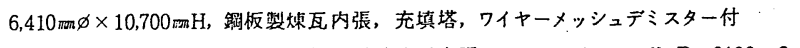 \\
\hline $\begin{array}{l}\text { 乾嬠塔用酸冷却タン } \\
\text { ク英ポンプタンク }\end{array}$ & 1 & $\begin{array}{l}\text { 10,000 } \varnothing \varnothing \times 2,900 \mathrm{ma} \mathrm{H}, \text { 豎型，虽板製耐酸煉瓦内張，テフロンクーラーNa D-3100-2 } \\
-19, \text { DOUBLE } 13 \text { 基 }\end{array}$ \\
\hline 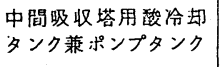 & 1 & 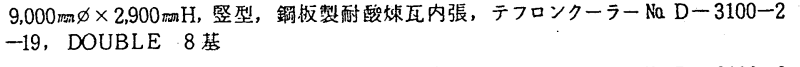 \\
\hline $\begin{array}{l}\text { 最終吸収塔用酸冷却 } \\
\text { タンク萧ポンプタンク }\end{array}$ & 1 & 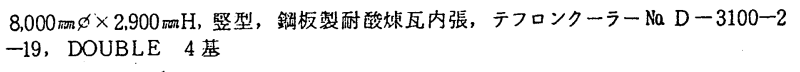 \\
\hline 筑硫塔循器ポンプ & 3 & $800 \mathrm{M}^{3} / \mathrm{h} \times 21 \mathrm{MH} \times 150 \mathrm{hw}$ ，堅型淁液式趑心ポンプ \\
\hline ガスブロアー & 1 & $2,100 \mathrm{Nm} / \mathrm{min} \times 5,000 \mathrm{man} \mathrm{Aq} \times 3,100 \mathrm{kw} ， 1$ 段両的込型ターボ \\
\hline 交 换 & 6 & 堅型直交流多管式， $2,730 \mathrm{M}^{2} \times 2,2,710 \mathrm{M}^{2} \times 1,2,500 \mathrm{M}^{2} \times 1,2,060 \mathrm{M}^{2} \times 2$ \\
\hline 化 & 1 & $11,000 \mathrm{mn} \varnothing \times 13,100 \pi \mathrm{m} \mathrm{H}, 4$ 層棚板式，触媒量 $=210 \mathrm{M}^{3}$ (モンサント，東洋 $\left.\mathrm{CCI}\right)$ \\
\hline 製品酸冷却タンク & 1 & 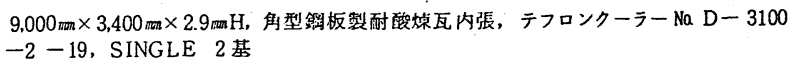 \\
\hline 眝 酸 タンク & 1 & 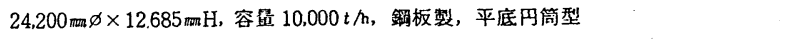 \\
\hline 焼 鉱 眝 鉱 金 & 1 & 鉄骨スレート萁， $72,000 \mathrm{ma} \mathrm{L} \times 20,000 \mathrm{~mm} \mathrm{~W}$, 眝鉱能力 $3,600 \mathrm{t}$ \\
\hline
\end{tabular}

第 4 表 (1)
内直接冷却水として使用するだけで 水バランスを保つことは可能である が, 循環酸の中に蓄積する一部の成 分のために, 硫化反応槽で硫化物と して循環系から沈降分離する設備を 設置した。

硫化処理後の上澄液は工程内に繰 返し使用し, 廃酸・廃液は完全なク ローズドシステムが確立している。

\section{3. 高品位酸化鉄製造部門}

当社の柵原鉱山産出の硫化鉄鉱は， 埋蔵鉱量の豊富さと優れた品質の面 で高く評価され, 硫酸の原料鉱石と しては古くより広く国内で使用され てきたが, 鉄分については僅かに製 鉄用の燒結鉱原料として戦後使用さ れるようになつたに過ぎない。

高品位酸化鉄製造の研究は, この 柵原鉱の高度利用, すなわち, より 付加価値の高い製品への脱皮を求め てまず鉄資源として見直し活用する ため, 重液選鉱・浮遊選釷等により さらに純度の高い硫化鉄鉱として脈 石成分から分離することから開始さ れた。

柵原鉱石は母岩が鉱石と混入して 採掘されることは少なく, 細粒の黄 鉄鉱結晶の集合体を形成して, 顕微 鏡下では硫化鉄鉱を主体とし, その 結晶間隙に充填している僅少量の黄

\section{〔焙焼設備〕}

\begin{tabular}{|c|c|c|c|}
\hline 給 鉱 量 & 14. $5 \sim$ $\sim 6.0 \mathrm{t} / \mathrm{h}$ & 送風 量 & $\begin{array}{l}36,000 \sim \\
38,000 \mathrm{Nm}^{3} / \mathrm{h}\end{array}$ \\
\hline ベット温度 & $930 \sim 950^{\circ} \mathrm{C}$ & $\begin{array}{r}\text { フリーボード } \\
\text { 温 }\end{array}$ & $880 \sim 900^{\circ} \mathrm{C}$ \\
\hline ウィンドボ & $+2,200 \sim$ & フリーボード & $-10 \sim$ \\
\hline ックス圧力 & $+2.500 \mathrm{~mm} \mathrm{Aq}$ & & $-40 \mathrm{~mm} \mathrm{Aq}$ \\
\hline \multicolumn{4}{|l|}{ [ボイラー ] } \\
\hline 入ロガス温度 & $880 \sim 900^{\circ} \mathrm{C}$ & 出ロガス温度 & $350 \sim 410^{\circ} \mathrm{C}$ \\
\hline 入ロガス含塵量 & $220 \mathrm{~g} / \mathrm{Nm}^{3}$ & 出ロガス圧力 & $\begin{array}{l}-40 \sim \\
-50 \mathrm{~mm} \mathrm{Aq}\end{array}$ \\
\hline 蒸気 流 量 & $\begin{array}{l}\text { 15. } 0 \sim \widetilde{16.5} \mathrm{t} / \mathrm{h}\end{array}$ & 過熱蒸気温度 & \\
\hline \multicolumn{4}{|c|}{ [サイクロン] } \\
\hline $\begin{array}{cc}\text { 出 } \text { ロ } \\
\text { 含 塵 量 }\end{array}$ & $10 \sim 15 \mathrm{~g} / \mathrm{Nm}^{3}$ & 出口ガス圧力 & $\begin{array}{l}-200 \sim \\
-260 \mathrm{~mm} \mathrm{Aq}\end{array}$ \\
\hline \multicolumn{4}{|c|}{ [ピーボディ塔 ] } \\
\hline 出ロガス温度 & $38 \sim 42^{\circ} \mathrm{C}$ & 出ロガス圧力 & $\begin{array}{l}-480 \sim \\
-650 \mathrm{~mm} \mathrm{Aq}\end{array}$ \\
\hline $\begin{array}{l}\text { 循環 酸入口 } \\
\text { 温 }\end{array}$ & $25 \sim 28^{\circ} \mathrm{C}$ & $\begin{array}{l}\text { 循 環 酸出口 } \\
\text { 温 }\end{array}$ & $60 \sim 68^{\circ} \mathrm{C}$ \\
\hline 循環 酸成分 & \multicolumn{3}{|c|}{$\begin{array}{ll}\mathrm{Cu}=0.2 \sim 0.3 \mathrm{~g} / l & \mathrm{Fe}=7 \sim 15 \mathrm{~g} / l \\
\mathrm{CaO}=0.4 \sim 0.8 \mathrm{~g} / \mathrm{h} & \mathrm{SO}_{3}=30 \sim 50 \mathrm{~g} / l\end{array}$} \\
\hline \multicolumn{4}{|c|}{ [ミストコットレル] } \\
\hline 出口ミスト量 & $\begin{array}{l}5 \sim 15 \mathrm{mg} \\
\mathrm{H}_{2} \mathrm{SO}_{4} / \mathrm{Nm}^{3}\end{array}$ & 出ロガス圧力 & $\begin{array}{l}-650 \sim \\
-700 \mathrm{~mm} \mathrm{Aq}\end{array}$ \\
\hline
\end{tabular}

〔ガスブロア]

\begin{tabular}{|c|c|c|c|c|}
\hline 入ロガス量 & \multicolumn{4}{|c|}{$115,000 \sim 130,000 \mathrm{Nm}^{3} / \mathrm{h}$} \\
\hline 出ロガス組成 & \multicolumn{4}{|c|}{$\begin{array}{l}\mathrm{SO}_{2}=8.5 \sim 9.7 \% \quad \mathrm{O}_{2}=8.2 \sim 10.0 \% \\
\mathrm{O}_{2} / \mathrm{SO}_{2}=0.92 \sim 1.05\end{array}$} \\
\hline \multicolumn{5}{|c|}{ [乾燥・吸収塔] } \\
\hline & & 乾 燥 塔 & 第 1 吸収塔 & 第 2 吸収塔 \\
\hline 循環酸滴酸濃度 & $\%$ & $94.8 \sim 95.4$ & $98.2 \sim 98.8$ & $98.2 \sim 98.8$ \\
\hline " 温度 & ${ }^{\circ} \mathrm{C}$ & $35 \sim 40$ & $65 \sim 73$ & $70 \sim 75$ \\
\hline " 落口酸温度 & ${ }^{\circ} \mathrm{C}$ & $45 \sim 52$ & $90 \sim 95$ & $85 \sim 90$ \\
\hline 塔圧損(充塤部) & mmAq & 80 & 85 & 65 \\
\hline "（デミスター部） & $\mathrm{mmAq}$ & 25 & 30 & 30 \\
\hline
\end{tabular}

[転化器]

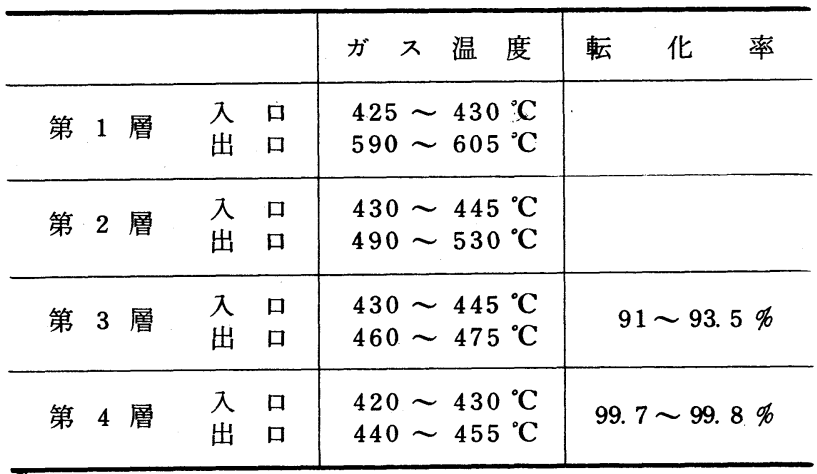


第 4 表 (2)

\begin{tabular}{|c|c|c|c|}
\hline $\begin{array}{l}\text { タービン } \\
\text { 主蒸気流量 } \\
\text { タービン } \\
\text { 主蒸気圧力 }\end{array}$ & $\begin{array}{l}25.0 \sim \\
\quad 29.5 \mathrm{t} / \mathrm{h} \\
\text { 29. } 8 \sim \\
\text { 30. } 2 \mathrm{~kg} / \mathrm{cm}^{2} \mathrm{G}\end{array}$ & $\begin{array}{l}\text { タービン } \\
\text { 主蒸気温度 } \\
\text { タービン発電量 }\end{array}$ & $\begin{array}{l}330 \sim 355^{\circ} \mathrm{C} \\
5,000 \sim 5,700 \mathrm{~kW}\end{array}$ \\
\hline \multicolumn{4}{|l|}{ 〔排煙脱硫〕 } \\
\hline $\begin{array}{l}\text { 吸収溚入口 } \\
\mathrm{SO}_{x} \\
\mathrm{SO}_{x} \text { 出口 } \\
\text { 脱硫効率 }\end{array}$ & $\begin{array}{l}350 \sim 700 \mathrm{ppm} \\
5 \sim 20 \mathrm{ppm} \\
96 \sim 98.5 \%\end{array}$ & $\begin{array}{c}\text { 吸收塔出口 } \\
\text { 度 } \\
\text { " 圧損失 }\end{array}$ & $\begin{array}{l}27 \sim 28^{\circ} \mathrm{C} \\
150 \sim 250 \mathrm{mmAq}\end{array}$ \\
\hline
\end{tabular}

銅鉱 $\left(\mathrm{CuFe} \mathrm{S}_{2}\right)$ 抢よびセン亜鉛鉱 $(\mathrm{ZnS})$ を伴つている。脈 石としては石英が最も普遍的で網状，脈状に鉱石鉱物の間を充填 していることが知られていた ${ }^{4)}$ 。このような鉱体状態・鉱物組織か らみて, 200meshに粉砕して浮選することによつて, 不純物の少 ない硫化鉄鉱を得ることに成功した。

1965 年に至り, 試験室のデータを基礎にした浮選工程・焙焼 工程・ガス処理工程からなるパイロットプラントを設置して, 高 品質の硫化鉄鉱の分離ならびに焙焼炉による脱硫等のテストを開 始した。試作品である高品位酸化鉄は同和鉄粉工業(株)の協力を 得て, 粉末冶金用鉄粉 - 溶接棒用鉄粉の原料として, または顔料 用酸化鉄等の粗原料としての特性の研究に当てられ, 用途開発の ための試供品が製造された。

1968 年 4 月には, 高品位酸化鉄月産 $430 \mathrm{t}$ の商業べースによ る生産を開始し, 製品は主として同和鉄粉工業(株)一出荷された。 さらにフェライト磁石用酸化鉄の分野への研究を続け, 従来硫 酸鉄や塩化鉄から製造された酸化鉄で占められていた市場に対し， 天然鉱石である硫化鉄鉱を原料として, 従来のものと異なる特性 を有する新しい酸化鉄原料としての用途を確保することができた。 この間フェライト磁石用酸化鉄ならびに粉末治金用鉄粉原料とし て要求される化学組成・粉体物性などの研究は, 岡山研究室の協 力を得ておこなわれ, 販売面では着実に市場を抎大することに成
第 5 表 原料・浮選精鉱の品位

\begin{tabular}{l|c|c|r|l|l|r}
\hline & $\mathrm{S}$ & $\mathrm{Fe}$ & \multicolumn{1}{c|}{$\mathrm{Cu}$} & $\mathrm{Zn}$ & $\mathrm{Pb}$ & $\mathrm{Si} \mathrm{O}_{2}$ \\
\hline 選鉱原鉱 & 49.64 & 44.56 & 0.14 & 0.29 & 0.01 & 2.50 \\
硫化精鉱 & 52.42 & 46.46 & 0.02 & 0.06 & 0.01 & 0.10 \\
銅 精 鉱 & 33.72 & 30.10 & 19.03 & 2.86 & 0.03 & 0.13 \\
硫化尾鉱 & 34.15 & 36.89 & 0.28 & 1.43 & 0.02 & 11.24 \\
\hline
\end{tabular}

第 6 表 高品位酸化鉄の粒径および主要成分

\begin{tabular}{c|c|c|c|c|c|c}
\hline 平均粒径 $(\mu)$ & \multicolumn{3}{|c}{ 成 } & \multicolumn{4}{c}{ 分 } \\
\hline \multirow{2}{*}{$1.10 \pm 0.05$} & $\mathrm{Fe}_{2} \mathrm{O}_{3}$ & $\mathrm{SiO}_{2}$ & $\mathrm{~S}$ & $\mathrm{Cu}$ & $\mathrm{Zn}$ & 水 分 \\
& 99.20 & 0.20 & 0.03 & 0.05 & 0.10 & 0.2 \\
\hline
\end{tabular}

功して, 1970 年 10 月には月産 $2,500 \mathrm{t}$ の生産設備が完成した。 現在さらに旺盛なマグネット業界の需要に応じるために増産工事 に着手している。

$3 ・ 1$ 設備ならびに操業の概要 ${ }^{5) 6) 7) ~}$

製品の大部分をフェライト磁石用の酸化鉄としての販路で市場 に送つているので, 求められる粉体特性もそれによつたものとし ている。成分品質としては, $\mathrm{Fe}_{2} \mathrm{O}_{3}$ が $99 \%$ 以上, その他成分と しては $\mathrm{SiO}_{2} \quad 0.25 \%$ 以下, $\mathrm{Zn} 0.10 \%$ 以下, $\mathrm{Cu} \quad 0.05 \%$ 以下, S $0.03 \%$ 以下であり, 製品の粒径は, 平均粒子径 $1 \mu$ である。

原料鉱石は上記のように, 柵原鉱山産の硫化鉄鉱を柵原鉱業所 で粉䂶し，重液選鉱したものを選鉱原鉱として使用している。

製造工程は第 2 図に示すとおりであるが，選鉱・焙焼・再焙焼 微粉砕の各工程から成つている。以下工程を追つて説明する。

$3 \cdot 1 \cdot 1$ 選鉱工程原料の柵原硫化鉄鉱をボールミルで摩 鉱した後, 浮選機 (\#36アジテア 32 区) で浮選し $\mathrm{Cu}, \mathrm{Zn}, \mathrm{SiO}_{2}$ などの不純物を所定の品質まで除去する。この工程で得られた硫 化精鉱が次の焐焼工程へ給鉱される。選鉱工程における原鉱・精 鉱の品位は第 5 表のとおりである。

$3 \cdot 1 \cdot 2$ 焙焼工程 浮選精鉣は湿式給鈗によりドル式流動 焙焼炉 ( $8.4 \mathrm{~m} \phi)$ で脱硫焙焼する。焙焼炉の操業条件は硫酸工 場と同様に, 师内の酸素分圧を精密に調整し焙焼焼鉱の特性の向
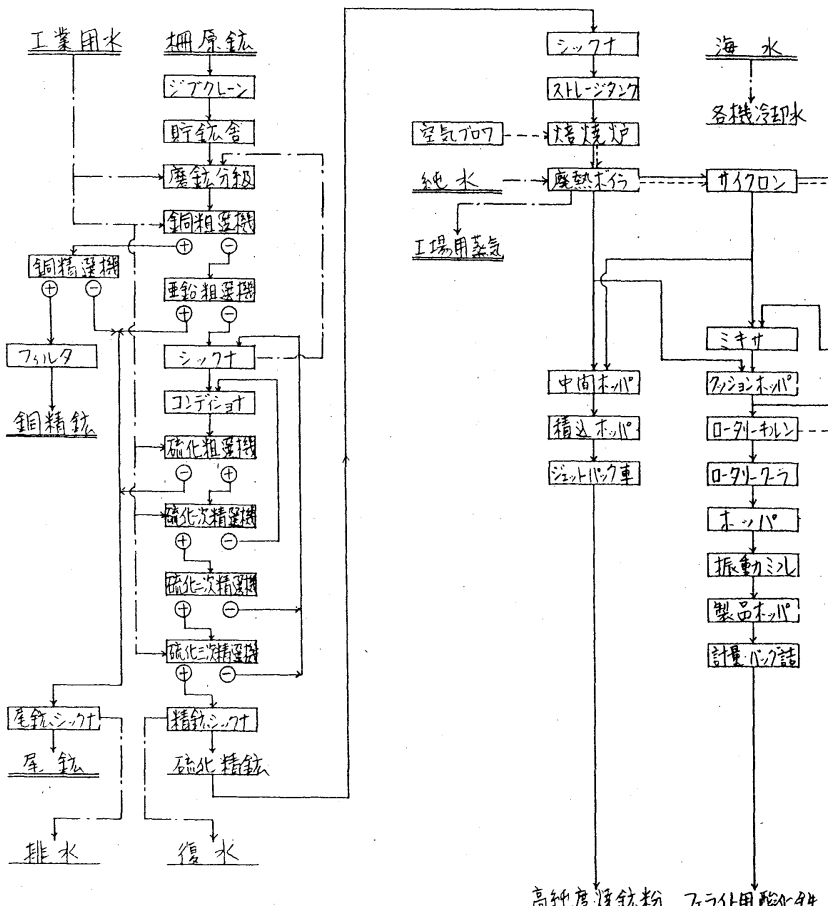

第2図酸化鉄部門設備系統図

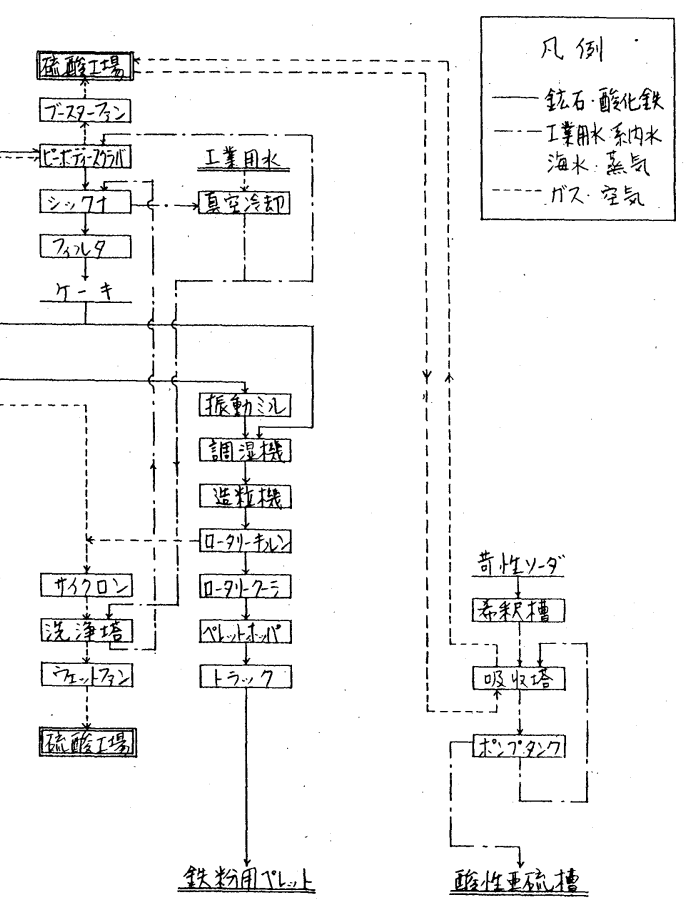

金失粉用 $70^{\circ}$. 
原田・小野崎：同和鉱業岡山:製鍊所 $\square$

第 7 表 排煙脱硫設備 (塩基性硫酸アルミ石膏法 )

\begin{tabular}{|c|c|c|}
\hline 供 & 勘 数 & 式・仕 \\
\hline 排 脱 吸 収 塔 & 2 & $\begin{array}{l}5,800 \mathrm{~mm} \varnothing \times 20,100 \mathrm{~mm} H, \text { 銅板制内面耐酸ライニング, 克填塔, ワイヤーメッシニデミス } \\
\text { ター内蔵 }\end{array}$ \\
\hline 化 & 2 & 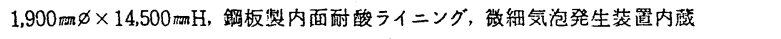 \\
\hline 吸収液偱環ポンプ & 3 & $550 \mathrm{M}^{3} / \mathrm{h} \times 30 \mathrm{MH} \times 90 \mathrm{kw}$ ，耐酸ラバーライニングポンプ \\
\hline 空 気 壬 縮 機 & 2 & $2,750 \mathrm{Nm} / \mathrm{h} \times 3.0 \mathrm{~kg} / \mathrm{cm}^{2} \mathrm{G} \times 260 \mathrm{kw}$ \\
\hline 和 & 4 & $3,860 \mathrm{~mm} \varnothing \times 5,800 \mathrm{~mm} \mathrm{H}$, 下部円錐型, 鋼板製内面聇酸ライニング, 空気摚拌方式 \\
\hline 枕降 & 2 & 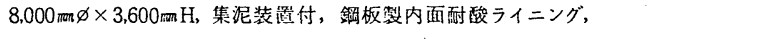 \\
\hline ミストコットレル & 1 & $7,620 \mathrm{~mm} \times 5,370 \mathrm{~mm} \times 7,800 \mathrm{rm} H$, 垂直流平板式, FRP製 \\
\hline 排 ガスプン & 2 & $2,960 \mathrm{NM}^{3} / \mathrm{min} \times 500 \mathrm{~mm} \mathrm{Aq} \times 450 \mathrm{kw}$ \\
\hline 遠 心 分 離 機 & 3 & AT－55型，自動運転底排型，SUS 316製，部分ゴムライニング \\
\hline 体＼cjkstart合＼cjkstart煙 & 1. & $2,400 \operatorname{man} \varnothing \times 55,000 \min \mathrm{H}$, 先端 $2,000 \operatorname{mon}, \mathrm{FRP}$ 製 \\
\hline
\end{tabular}

酸化工程; $\mathrm{Al}_{2}\left(\mathrm{SO}_{4}\right)_{3}+\mathrm{Al}_{2}$ $\left(\mathrm{SO}_{3}\right)_{3}+3 / 2 \mathrm{O}_{2}$ $\rightarrow 2 \mathrm{Al}_{2}\left(\mathrm{SO}_{4}\right)_{3}$ 中和工程 $;_{2} \mathrm{Al}_{2}\left(\mathrm{SO}_{4}\right)_{3}+3$ $\mathrm{Ca} \mathrm{CO}_{3}+6 \mathrm{H}_{2} \mathrm{O}$ $\rightarrow \mathrm{Al}_{2}\left(\mathrm{SO}_{4}\right)_{3}$. $\mathrm{Al}_{2} \mathrm{O}_{3}+3\left(\mathrm{Ca} \mathrm{SO}{ }_{4}\right.$ . $\left.2 \mathrm{H}_{2} \mathrm{O}\right)+3 \mathrm{CO}_{2}$ 以下順を追つて説明する。

$4 \cdot 1 \cdot 1$ 吸収工程 実操業に おいては, 硫酸工場の排ガスは, 70 ${ }^{\circ} \mathrm{C}, \mathrm{SO}_{x}$ 濃度 $350 \sim 700 \mathrm{ppm}$ で吸収 塔に導入される。 $\mathrm{SO}_{x}$ の殆んどが塔

上をはかつている。焼鉱は全量焙焼ガスとともにキャリオーバし， 廃熱ボイラ, サイクロン, ピーボディ塔で回収され, $\mathrm{SO}_{2}$ ガスは 硫酸製造工程に送気されている。

$3 \cdot 1 \cdot 3$ 再焙焼工程回収した焼鉱 (酸化鉄) には, 残留 硫黄分が製品規格を上迴つて含有されているので, ロータリーキ ルン $(1.8 \mathrm{~m} \phi \times 2.5 \mathrm{~mL})$ を用いて, 再焙焼して $\mathrm{S}<0.03 \%$ で脱硫している。

$3 \cdot 1 \cdot 4$ 微粉砕工程 再焙焼工程で脱硫した酸化鉄を乾式 連続振動ボールミル $(0.5 \mathrm{~m} \phi \times 3.0 \mathrm{~mL}) 6$ 基により微粉砕し製 品とする。粒径の規格は, サブシーブサイザによる平均粒子径に よる測定値をもつて表示している。

製品の粒径ならびに主要成分は；第 6 表に示した。

\section{4. 排煙脱硫部門}

市街地に隣接して設立された硫酸工場である岡山製鍊所にとつ ては, 排煙脱硫技術の開発は極めて重要な課題であつた。1953 年の製鍊所がスタートした時に, 当時は一般的に硫酸設備や製鍊 設備に排煙の処理装置がほとんど設置されていない時代であつた が, 独自の研究に基づく「海水吸収石灰石膏法」による処理設備 がすでに建設されていた。これは, 現在の技術水準からみれば効 率等で満足されるものではなかつたが, 当時はそれなりの成果を あげることができた。1957 年以降は「亜硫酸ソーダ法」に変更 され, 現在の「塩基性硫酸アルミニウム =石高法」の技術が開発 された ${ }^{8) 9) 10) 。 ~}$

原料苛性ソーダ価格の異常上昇に加えて亜硫酸ソーダや酸性亜 硫酸ソーダの需要の停滞などの要因が重なり, しかも環境規制が 重視されるなかでのB 系プラントの増設であつたため, 斬新な方 法に基づく大型の排煙脱硫設備の開発が必要であつた。この塩基 性硫酸アルミ方式は当社岡山研究室と当所が協同して開発し完成 を見たもので今日まで順調な操業を継続している。また，この方 式によるプラントは関係会社である同和工営 (株)によつて国内の 幾つかの製鍊所, 発電所等に建設され好評を得ている。

\section{$4 \cdot 1$ 設備ならびに操業の概要}

設備のフローシートは第 1 図主要設備仕様は第 7 表のとおりで, 設備の設計条件をつぎに示す。

$\begin{array}{lc}\text { 最大ガス処理量 } & 150,000 \mathrm{Nm}^{3} / \mathrm{H} \times 2 \text { 基 } \\ \text { 通常ガス処理量 } & 120,000 \mathrm{Nm}^{3} / \mathrm{H} \times 2 \text { 基 } \\ \text { 設計ガス濃度 }\left(\mathrm{SO}_{x}\right) & 800 \mathrm{ppm} \\ \text { 脱硫効率 } & 95 \% \text { 以上 }\end{array}$

このプロセスは，大きく分類すると次の 4 つの工程に分れる。 各工程をモデル化して, 化学反応式で表すとつぎのようになる。 吸収工程; $\mathrm{Al}_{2}\left(\mathrm{SO}_{4}\right)_{3} \cdot \mathrm{Al}_{2} \mathrm{O}_{3}+3 \mathrm{SO}_{2}$

$$
\rightarrow \mathrm{Al}_{2}\left(\mathrm{SO}_{4}\right)_{3}+\mathrm{Al}_{2}\left(\mathrm{SO}_{3}\right)_{3}
$$

内で循環液中に吸収され, 塔出口の排ガスは $27^{\circ} \mathrm{C}, \mathrm{SO}_{x} 5 \sim 20$ ppm 水分飽和であるが, 集合煙突からの排出端では, 白煙はま つたく認められない。

$4 \cdot 1 \cdot 2$ 酸化工程 $\mathrm{SO}_{x}$ を吸収した循環液は酸化塔に送 液して空気酸化をさせる。

酸化塔は, 塔底部に設置した特殊ノズルの効果によつて, 極め て微細な気泡を発生させ，効率よく酸化させることができる。

酸化塔出口の大部分の液量は, 再び吸収塔一灌液させている。

$4 \cdot 1 \cdot 3$ 中和工程 吸収塔内で吸収した $\mathrm{SO}_{x}$ 量に相当する $\mathrm{SO}_{x}$ 量を中和工程で石膏として固定し, 循環夜の系外に分離する ことが必要で, 酸化塔出口液の一部を中和反応槽へ導いて, 炭酸 カルシウムで中和している。中和槽へは, このほか, 結晶の粗大 化をはかるための種晶の繰返えし供給も実施している。

このプロセスでは, 塔内で吸収した $\mathrm{S} \mathrm{O}_{x}$ 量相当の中和反応を 過不足なくコントロールすることが, きわめて重要な管理ポイン トであるが, 独自の方法によつて塩基量の検出をし, 中和工程へ の抜出夜量, または, 中和工程に㧍ける中和剤の使用量のコント ロールを実施している。

4・1・4 石膏分離工程 生成した石膏は, 沈降槽で濃縮し, 遠心分離機によつて沪過・洗浄・脱水をする。洰液ならびに洗浄 水は全量工程水として吸収塔の循環液に補給し, 水バランスを保 つている。玩在, 生成した石高は全量焼石膏用として外販してい る。中和用炭酸カルシウムならびに製品石高の品質を第 8 表に示 す。

\section{5.むすび}

以上, 硫酸センター設立以降の当所の歩みを概説してみた。こ の期間の前半はスクラップ・アンド・ビルドによる生産設備の拡 大と技術革新による操業合理化への追究であつたが, 細部を除き この当初の目的のあらましはほぼ達成されたものと考えている。

しかし, オイル・ショックを契機として日本経済が高度成長か ら安定成長へ軌道修正された今日, すべての産業にわたつて, 規 模の拡大より能率の向上・省資源・省エネルギーの重要性が再認 識されるようになり, 当所としても操業管理の面でより一層キメ の細かい合理化を押し進める必要に迫られている。最近に至り, 廃熱の回収や電力・燃料の節减等で次第に効果が現われてきては いるものの, なお時代に即したプラントへの体質改善への課題は 多く残されているというべきであろう。

また，従来硫酸涬として製鉄用焼結原料でしかあり得なかつた 焼鉱が遺利の回収により高炉用ペレットとしてよみがえつたばか りでなく, フェライト磁石原料という新たな分野へ飛踓したわけ であるが, 今後はより付加価値の高い加工品の分野へ進展するこ とが新たな課題となるであろう。このような努力により硫化鉄鉱 
第 8 表 炭酸カルシウム・石膏の品位

\begin{tabular}{l|c|c|c|c|c|c|c|c}
\hline & $\mathrm{CaO}$ & $\mathrm{CO}_{2}$ & $\mathrm{SO}_{3}$ & $\mathrm{Al}_{2} \mathrm{O}_{3}$ & $\mathrm{MgO}$ & $\mathrm{Fe}$ & $\mathrm{Mn}$ & 附着水分 \\
\hline $\begin{array}{l}\text { 炭酸カル } \\
\text { シウム }\end{array}$ & 55.28 & 39.93 & - & 0.03 & 0.20 & 0.01 & 0.003 & - \\
石 亳 & 32.32 & - & 46.78 & 0.06 & 0.02 & 0.02 & 0.002 & 6.2 \\
\hline
\end{tabular}

の潜在価值を押し上げることが，すなわち当製鍊所の体質強化一

つながるものと考えている。

$$
\text { 参 考 文 献 }
$$

1）四元：日本鉱業会誌, VoI. $84(1968-7)$ p. 198
2）原田：硫酸と工業，Vol. $23(1970-10)$ p. 295

3）大塚ほか：同上, Vol.30,(1977-7) p. 161

4）新井：日本鉱業会誌, Vol. 78 (1962-2)

5）大塚ほか：粉体および粉末治金，Vol.20 $(1973$ - 4) p. 126

6）金谷：エレクトロ・セラミクス, Vol.4（19735) p. 9

7）小野崎ほか：日本鉱業会誌，Vol. 96 (1980-4) p. 270

8）山道ほか：石高と石灰，130号（1974）

9）山道ほか：硫酸と工業, Vol. $27(1974-1,1)$

10）小野崎ほか：日本鉱業会誌, Vol. 91 （1975－4） p. 316

\section{Recent Improvement of Pyrite Utilization in Okayama Plant, Dowa Mining Co., Ltd.}

\section{by Kenzo HARADA and Atsuo ONOZAKI}

Okayama Plant, Dowa Mining Co., Ltd., was established in 1953 for the effective utilization of domestic pyrites. In 1969 , it added to its facilities a large-scale double-contact sulfuric acid plant which utilizes the scrap and build system. The expansion of facilities in 1974 turned Okayama Plant into one of the largest such manufactories of the nation, and it is contributing to the stable supply of sulfuric acid through intensive treatment of pyrites. The total full capacity of the facilities is $800,000 \mathrm{mtpy}$ of sulfuric acid and oleum.

The pyrite cinders produced in this process is treated at the Tobata Plant and the Amagasaki Plant of Dowa's affiliate companies to make iron pellets for steel production, and the recovery of valuable metals is also carried out by means of the chloridizing volatilization.

On the other hand, in 1970, a train of facilities to produce the high-grade ferric oxide for raw materials of ferrite magnets was constructed to permit the high-level utilization of pyrites from Yanahara Mine. In this process, the raw materials are ground and polished up to high grade pyrite concentrates remaining less than $0.15 \%$ of $\mathrm{SiO}_{2}$ by flotation and roasted in a fluidized-bed roaster. The calcine is then re-roasted in a rotary kiln to reduce its sulfur content less than $0.03 \%$, and finely ground by vibromills down to $1 \mu \mathrm{m}$ in average diameter. The production of the ferric oxide is $28,000 \mathrm{mtpy}$ in total.

Okayama Plant provides an unique and perfect desulfurizing process for the waste gas treatment using basic aluminum sulfate solution as absorbent. Pregnant solution is neutralized by limestone after air oxidation and, eventually, the sulfur oxide in waste gas is eliminated as the gypsum. This process is developed in Okayama and several plants are now being operated
successfully inside and outside of Japan.

\section{〔3-22〕四阪工場における鉄鋼ペレットからの亜鉛，鉛の回収}

\section{1. 緒}

\section{$\overline{\overline{\overline{⿳ 亠 二 口}}}$}

住友金属鉱山(株) 別子事業所四阪工場における鉄鋼ペレット処 理は，明治38年から続けられた銅溶鉱炉操業が東予工場に集中す ることに伴い昭和51年末に休止し，その火を受け継いで銅涬灯の 操業が昭和 51 年 2 月より開始され ${ }^{1)}$, それに続く 2 本目の柱とし て, 昭和 52 年 8 月に設備が完成し, 同 9 月より操業に入つた。鉄 鋼ペレット処理は, 銅㳯炉操業と同様, 省資源, 資源リサイクル をめざしたもので，特に海外鉱の依存度の高いわれわれ製鍊業に とつて, 国内鉄鋼メ一カから発生する亜鉛, 鉛等の有価金属を含 有したペレットから亜鉛, 鉛を回収, 商品化することは有利であ り，しかも社会的ニーズにもかなうものといえる。

そこで当社四阪工場には, 永年溶鉱炬で培われた個有技術をも つていること, 遊休設備の利用が計れること, 海上輸送が可能で あること，すでに銅涬炉操業で一部鉄鋼ベレットの処理を行なつ ていたこと, 回収した亜鉛, 鉛等の有価金属は住鉱 I S P (現当 社播磨事業所)にて製品化ができるという有利な条件から，この

1. 正会員 住友金属鉙山株式会社別了事業所四阪工場長

2. 住友金属鉱山株式会社別子事業所四阪工場生産課

\section{安川元 弘 ${ }^{1}$ 桑田 寛 $^{2}$}

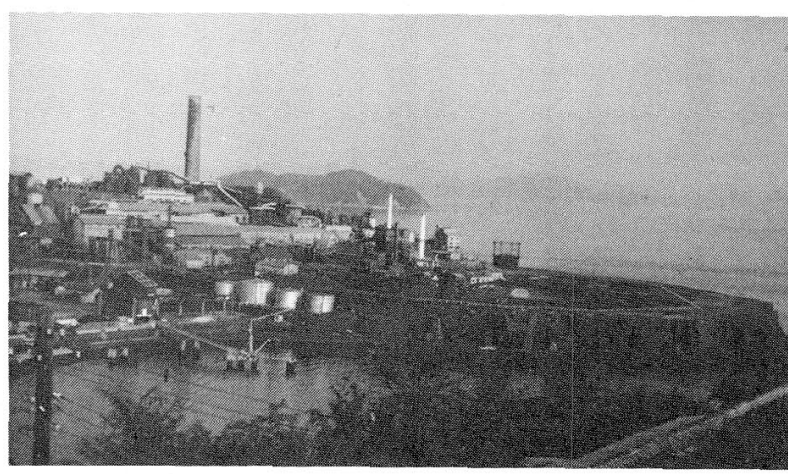

第 1 図四阪工場

事業に着手することになつた。処理能力 $50,000 \mathrm{t} /$ 年で設備計画 した。操業開始来 3 力年を経て, 当初の計画処理量を達成し安定 操業を維持するに至つている。その操業の概要について以下に報 告する。

\section{2. 設 備 の概 要}

鉄鋼ペレットから $\mathrm{Zn}, \mathrm{Pb}$ の揮発除去は, 燃料率, 回収率の有 